\title{
CURRENT STATE AND TRENDS OF THE NATIONAL ECONOMY OF SOCIAL CAPITAL DEVELOPMENT OF UKRAINE
}

\author{
Yurii Malakhovskyi ${ }^{1}$, Ali Kanso ${ }^{2}$
}

\begin{abstract}
The purpose of the publication is to summarize the practice of quantitative assessment of the current state and trends in the change of social capital of national economy (SCNE) of Ukraine on the basis of the use of the index system, which comprehensively take into account numerous aspects of its functioning as a basic factor in ensuring stable competitiveness of the national economy (NE), high level of human development, key conditions for prosperity and well-being of all segments of the population. The results of the benchmarking of indices and analysis of the actual level of SCNE are based on data about the factors of current level of the national economy's formation for individual countries in the process of ensuring in the strategic perspective the UN Sustainable Development Goals - Measuring Social Capital (SC) for Sustainable Development Goals (SDG). For SCNE of Ukraine is inherent in the simultaneous deep commitment of the domestic community to the values of survival (at the level of Russia, Moldova, Romania, Albania, Bulgaria) in combination with a high level of confession of secular rational values (at the level of Lithuania, South Korea, the Czech Republic, Germany, Denmark). Based on the above data, Ukraine has a low level of direct interpersonal social trust (the level of distrust/caution in relations practically exceeds it three times) combined with a low level of trust in political institutions. The necessary information for the assessment of the environment and the general level of development of SCNE of Ukraine is contained in the already mentioned international indices, which in their aggregate comprehensively characterize the subject of our research.
\end{abstract}

Key words: social capital of national economy, structural, relational and cognitive components of social capital, state and tendencies of change.

JEL Classification: A13, C43

\section{Introduction}

The SCNE, as a set of structured socio-economic relations, is based on mutually recognized informal institutions: norms and values, the observance of which ensures the growth of personal productivity of members of formed social networks, effective coordination and cooperation of individual actions for mutual benefit, manifested in the optimization of costs from the specification of property rights, their effective transformation, intensification of the level of interaction by minimizing the value of market transactions. A comprehensive study of the field of interdisciplinary relations of the main categories, the study of the peculiarities of their use in the process of formation of social networks and interpersonal norms and values is the basis for the periodization of the main stages of development of techniques and means of regulatory influence on the phenomenon of SC by the state: the formation of approaches to understanding

\footnotetext{
Corresponding author:

${ }^{1}$ Central Ukrainian National Technical University, Ukraine.

E-mail:yurmala@gmail.com

ORCID: https://orcid.org/0000-0003-0540-4429

${ }^{2}$ Central Ukrainian National Technical University, Ukraine.

E-mail: alikanso@ gmail.com

ORCID: https://orcid.org/0000-0003-4340-8105
}

the essence of the phenomenon; in-depth study of manifestation forms; expanding the list of constituent elements; development of the theory of functioning at the micro, meso- and macroeconomic levels of the economy; development of innovative means of development regulation in order to maximize the contribution to the welfare of the population.

The basic model of regulation of micro level's SC involves the use of means of authoritarian influence on the formation and strengthening of the structural, cognitive and relational component of egocentric social networks. Two-component model of functioning of SC of macro- and mesoeconomic level as a set of norms, values, relationships, beliefs of the individual that facilitate joint activities, perception of assistance and support from the outside, reciprocity, willingness to share resources, trust between participants involves the use of means of regulatory influence on identified components of institutional actors of the public 
sector (representatives of central executive bodies and local self-government), as well as stakeholders of the public sphere of mixed national economy with the separation of the structural and cognitive components in the functioning of social exclusive (bonding) social capital is a microeconomic social network of closely and strongly related individuals of egocentric homogeneous groups, which are formed in order to maximize the relief of the lives of community members in the everyday sense ("getting by life") (Rui, Covert, Stefanone \& Mukherjee, 2014). Sociable, inclusive (supporting) SC is a mesoeconomic social network of remote individuals, poorly connected through, at the same time, more significant than family, business ties between members of autogenic groups, which is used to advance in life ("getting ahead"), organizing a channel of "social elevator" (Villalonga-Olives, Adams \& Kawachi, 2016). Linking SC is a polystructural sociocentric network of individuals united within the national economy who occupy different positions in hierarchical structures, whose membership promotes access to the benefits of personal/social well-being with the assistance of official institutions (Carillo Alvarez, Riera-Romani, 2017).

The organizational and economic mechanism of regulation of the development of SCNE is defined as a structured system of behavioral aspects of the activities of subjects of public relations of the means of managerial and indicative influence on the configuration of regulatory objects subordinated to the purpose of implementation of social capital functions (Kanso, 2019). The complex nature of the organizational and economic mechanism is ensured by the inclusion of a number of substantive blocks in its composition. It was established that the potential ability of SC to maximize prolonged welfare reflects the established proportions between the attracted volumes of physical, natural, human, social, residual capital and the actual level of consumption of the population, and kinetic - formed under the influence of impulses of innovative social investment (Koval, Prymush, Popova, 2017).

The purpose of the publication is to summarize the practice of quantitative assessment of the current state and trends in the change of SCNE of Ukraine on the basis of the use of the index system, which comprehensively take into account numerous aspects of its functioning as a basic factor in ensuring stable competitiveness of the national economy (NE), high level of human development, key conditions for prosperity and wellbeing of all segments of the population.

\section{Methodology}

As an empirical base of the comparative positioning dynamics of the formation of SCNE of Ukraine, the World Value Survey (WVS-6) (World Values Survey:
Round Six, 2014) data were adopted. Given that the WVS-6 studies contain a significant - 371 - number complexly structured in 13 domains of indices, for sufficient to formulate conclusions, the researchers limited themselves to the family, informal and formal types of social capital, as well as its social and structural dimensions. In the process of choosing the optimal list of indicators, the need for a clear distinction between structural, social (relational) and cognitive dimensions of the nature of social capital is taken into account. Structural measurement, as envisaged by the purpose and logic of the research, describes the existence of social connections between different institutional actors of the national economy and their characteristics (density, hierarchy), social (relational) (reflects the settings and sensations within existing connections, cognitive) representation, interpretation, system of values and codes, language shared by participants of social networks $(\mathrm{CN})$ and which are most difficult to operate, because they relate to the general cultural context (Nahapiet \& Ghoshal, 1998; Baklanova, Petrova, Koval, 2020). In the course of generalization of relative indicators of evaluation of SCNE of Ukraine, the peculiarities of approach, known in scientific circles (Pichler \& Wallace, 2007), are taken into account, which is based on the results of calculating the indicators of the Euro barometer and the Qualityof-Life Research. To summarize the peculiarities of SCNE formation in Ukraine, a combination of WVS6 research results and approaches to the construction of quadrants of the Inglehart-Welzel matrix (WVS-6, 2014) was applied.

\section{Results}

The results of the benchmarking of indices and analysis of the actual level of SCNE are based on data about factors of current level of the national economy's formation for individual countries in the process of ensuring in the strategic perspective the UN Sustainable Development Goals - Measuring Social Capital (SC) for Sustainable Development Goals (SDG) (Sustainable Development Goals, 2020).

The latest publications include data on the actual value of 9 SCNE indices - Human Development, World Giving, Happy Planet, Corruption Perception, Global Peace, Global Competitiveness, Legatum Prosperity, Social Progress, Enabling Environment, as well as GDP per capita according to the IMF (according to PPP) and SDGI Bertelsmann to determine the current level of sustainable development of 193 countries, including 20 from the list of the most stable (Table 1).

Global Sustainable Competitiveness Index is determined taking into account the direct impact of SCNE on stabilization of the environment of the NE's development and saving the nation's natural capital (Table 2). 
Vol. 1, No. 4, 2020

Three Seas ECONOMic Journal

Table 1

Top 20 most stable countries in the world in the Measuring SC for SDG

\begin{tabular}{|c|c|c|c|c|c|c|c|c|c|c|c|c|c|}
\hline \multirow{2}{*}{ Country } & \multicolumn{13}{|c|}{ Index } \\
\hline & (1) & $(2)$ & (3) & (4) & $(5)$ & $(6)$ & (7) & $(8)$ & (9) & $(10)$ & (11) & $(12)$ & Rank \\
\hline Denmark & 11 & 16 & 2 & 2 & 5 & 10 & 1 & 2 & 4 & 9 & 1 & 6 & 1 \\
\hline Norway & 1 & $x$ & 3 & 7 & 20 & 16 & 2 & 1 & 5 & 2 & 8 & 6 & 2 \\
\hline Switzerland & 2 & 13 & 6 & 4 & 11 & 4 & 3 & 3 & 7 & 1 & 17 & 6 & 3 \\
\hline Iceland & 6 & $x$ & 4 & 11 & 1 & 24 & 10 & 6 & 8 & 6 & 14 & 8 & 4 \\
\hline New Zealand & 14 & 3 & 8 & 1 & 2 & 18 & 7 & 7 & 1 & 24 & 11 & 9 & 5 \\
\hline The Netherlands & 10 & 8 & 5 & 8 & 17 & 6 & 6 & 11 & 6 & 14 & 9 & 9 & 6 \\
\hline Finland & 12 & 25 & 1 & 3 & 14 & 11 & 5 & 4 & 11 & 17 & 3 & 10 & 7 \\
\hline Sweden & 8 & 29 & 7 & 4 & 18 & 9 & 4 & 5 & 9 & 12 & 2 & 10 & 8 \\
\hline Canada & 13 & 6 & 9 & 12 & 6 & 12 & 14 & 9 & 2 & 21 & 20 & 11 & 9 \\
\hline Germany & 4 & 18 & 17 & 9 & 22 & 3 & 8 & 8 & 25 & 18 & 6 & 13 & 10 \\
\hline Australia & 6 & 4 & 11 & 12 & 13 & 14 & 17 & 12 & 3 & 13 & 38 & 13 & 11 \\
\hline Ireland & 3 & 5 & 16 & 18 & 12 & 23 & 12 & 14 & 12 & 10 & 19 & 13 & 12 \\
\hline Austria & 20 & 15 & 10 & 12 & 4 & 22 & 13 & 20 & 14 & 15 & 5 & 14 & 13 \\
\hline Great Britain & 15 & 7 & 15 & 12 & 45 & 8 & 11 & 13 & 15 & 26 & 13 & 16 & 14 \\
\hline Singapore & 9 & 46 & 34 & 4 & 7 & 2 & 16 & 27 & $x$ & 11 & 66 & 20 & 15 \\
\hline Belgium & 17 & 42 & 18 & 17 & 18 & 21 & 22 & 19 & 16 & 19 & 16 & 20 & 16 \\
\hline The USA & 15 & 1 & 19 & 23 & 128 & 1 & 18 & 26 & 10 & 7 & 25 & 25 & 17 \\
\hline Japan & 19 & 107 & 58 & 20 & 9 & 5 & 19 & 10 & $x$ & 27 & 15 & 26 & 18 \\
\hline Spain & 25 & 58 & 30 & 30 & 32 & 26 & 25 & 17 & 22 & 33 & 21 & 29 & 19 \\
\hline Chile & 42 & 41 & 26 & 26 & 27 & 33 & 37 & 37 & 21 & 60 & 31 & 35 & 20 \\
\hline Ukraine & 88 & 101 & 133 & 126 & 150 & 83 & 96 & 80 & 46 & 131 & 41 & 98 & 21 \\
\hline
\end{tabular}

Source: Own calculation

Notes: (1) - Human Development (Human Development Reports, 2019); (2) - World Giving (World giving Index, 10 $0^{\text {th }}$ edition, 2019); (3) - Happy Planet (Helliwell, Layard, Sachs, 2019); (4) - Corruption Perceptions (Corruption Perception Index, 2019); (5) - Global Peace (Global Peace Index, 2019); (6) - Global Competitiveness (Global Competitiveness Index 4.0, 2018); (7) - Legatum Prosperity (The Legatum Prosperity Index, 2019); (8) - Social Development (Social Progress Index executive summary v.2.0, 2019); (9) - Favorable Environment (Enabling Environment Index, 2013); (10) - GDP per capita (PPP) (Gross National Income per capita, 2019); (11) - SDGI Bertelsmann (The SDG Index, 2019); (12) - average rank; (13) - position in the overall rating

Table 2

Positioning of SCNE in the process of determining GSCI of Ukraine

\begin{tabular}{|c|c|c|c|c|c|c|c|c|}
\hline \multirow{2}{*}{\multicolumn{2}{|c|}{ GSCI Component elements }} & \multicolumn{7}{|c|}{ Year } \\
\hline & & $2012^{*}$ & $2013^{*}$ & 2014 & 2016 & 2017 & 2018 & 2019 \\
\hline \multirow{2}{*}{ Natural capital } & Ukraine & $\frac{35.3}{126}$ & $\frac{31.6}{149}$ & $\frac{44.6}{103}$ & $\frac{44.6}{95}$ & $\frac{43.9}{92}$ & $\frac{44.0}{85}$ & $\frac{45.2}{80}$ \\
\hline & on average $^{* *}$ & 40.7 & 51.0 & 46.6 & 45.4 & 44.1 & 42,9 & 43.7 \\
\hline \multirow{2}{*}{$\begin{array}{l}\text { Effectiveness of } \\
\text { management }\end{array}$} & Ukraine & $\times$ & $\times$ & $\frac{47.6}{71}$ & $\frac{46.9}{87}$ & \multicolumn{2}{|c|}{$\frac{47.2}{100}$} & $\frac{47.1}{100}$ \\
\hline & on average & $x$ & $x$ & 45.6 & 46.3 & \multicolumn{2}{|c|}{49,3} & 48.6 \\
\hline \multirow{2}{*}{ Intellectual capital } & Ukraine & $\frac{37.3}{86}$ & $\frac{39.8}{76}$ & $\frac{44.6}{56}$ & $\frac{50.3}{35}$ & \multicolumn{2}{|c|}{$\frac{39.2}{80}$} & $\frac{47.8}{35}$ \\
\hline & on average & 38.1 & 38.6 & 37.5 & 37.4 & \multicolumn{2}{|c|}{37.2} & 35.5 \\
\hline \multirow{2}{*}{$\begin{array}{l}\text { Intensity and efficiency } \\
\text { of resources use }\end{array}$} & Ukraine & $\frac{43.5}{106}$ & $\frac{39.5}{147}$ & $\frac{31.7}{145}$ & $\underline{34.4}$ & \multicolumn{2}{|c|}{$\frac{39.5}{152}$} & $\frac{42.2}{147}$ \\
\hline & on average & 46.9 & 52.9 & 41.0 & 42,6 & \multicolumn{2}{|c|}{46.6} & 49.0 \\
\hline \multirow[t]{2}{*}{ Social capital } & Ukraine & $\frac{48.5}{48}$ & $\frac{53.7}{42}$ & $\frac{42.4}{75}$ & $\frac{46.5}{54}$ & \multicolumn{2}{|c|}{$\frac{45.3}{57}$} & $\frac{41.3}{87}$ \\
\hline & on average & 41.1 & 29.2 & 40.5 & 39.2 & \multicolumn{2}{|c|}{40.2} & 40.5 \\
\hline \multirow[t]{2}{*}{ Stable competitiveness } & Ukraine & $\frac{40.6}{74(186)}$ & $\begin{array}{c}\underline{41.0} \\
102(176)\end{array}$ & $\stackrel{42.2}{83(176)}$ & $\underline{44.6}$ & \multicolumn{2}{|c|}{$\frac{43.0}{91(180)}$} & $\begin{array}{c}\underline{44.7} \\
74(180) \\
\end{array}$ \\
\hline & on average & 39.5 & 41.9 & 41.8 & 42.5 & \multicolumn{2}{|c|}{43.2} & 43.3 \\
\hline
\end{tabular}

Source: The Global Sustainable Competitiveness Index, 2019

Notes: numerator - the value of the indicator; denominator - rank of indicator; ${ }^{* *}$ is the average for the set of evaluated countries;

$2012 / 2013^{*}$ - estimated indicators - natural capital; intensity and efficiency of resource use; stable innovation and competitiveness (the data is given in the line "intellectual capital"); social cohesion (the data is given in the line "social capital"). 
The list and content of specific indicators used to evaluate SCNE continues to be constantly transformed.

Since 2012, a kind of application for measuring the value of SKNE is found in Gross National Happiness (GNH) indicators. To measure it, a methodology for layout on 9 domains of 33 indicators of psychological well-being was developed. In list there are: health; time usage, education, cultural diversity and sustainability; good governance; viability of communal formations; environmental diversity and sustainability (Arsawan et al., 2020); living standards (Helliwell, Layard \& Sachs, 2019). According to the authors of this study, for an effective effect on the level of happiness and misfortune, it should be borne in mind that it is formed on the basis of the genetic characteristics of each individual. In addition, the person he or she becomes depends on the interaction of these genes with the environment he or she encounters. Together, genes and the environment define the main features of human life - both those that are very "personal" (mental and physical health, family experience, education, gender, age) and those that are recognized mainly as "external" (income level, work, community living, quality of management, prevailing values, religion). And these features, in turn, determine the well-being of a person (Petrova et al., 2020). Although work is an important part of social existence, human relationships are much wider and include relationships with family, friends and the community. This is obvious, because in the Maslow pyramid, the need for love and belonging arise immediately after the basic physiological needs and safety. That is, the sources of personality happiness include a set of social interactions through which people enter into mutual bonds. Accordingly, the quantity and quality of social relations in the community should be treated logically and logically as SC.
The Legatum Prosperity Index (LPI) (Table 3) enters its features in the calculation of SCNE. The basis of Ukraine's rating is based on weight-equal drivers, which characterize: social cohesion; communal and family networks as a form of volunteer activity; assistance to those in need; philanthropy; perception of social assistance; trust in others; level of marriages; religious tolerance.

Global Competitiveness Index 4.0 is formed according the World Economic Forum methodology by following list of indicators: favorable environment, human capital; market components; ecosystems.

Direct assessment of the country's SCNE (indicator $1.05)$ is carried out by the mentioned international institution in the process of calculating the element "Institution" of the first direction of calculations "Favorable environment", starting from 2018. The method of quantitative determination of the indicator is linear regression, and the regressors are: the actual number of years of study, the Corruption Perception Index, general trust among the population, as well as the level of GDP.

The World Giving Index allows you to evaluate each country in three indicators - helping needy strangers; charitable donations; time devoted to volunteer activities (World giving Index $10^{\text {th }}$ edition, 2019). It uses the opportunity to take into account gender and age aspects of philanthropy (Table 4).

The calculation of the SKNE Index as part of the World Giving Index, which shows the importance for different countries of indicators of the quality of economic development, functioning environment, quality of public administration (Bukanov et al., 2019), functioning of the education system, health care, protection and safety, personal freedom, the formation of SKNE and the quality of functioning of

Table 3

Rating of Ukraine in the process of calculating LPI indicators

\begin{tabular}{|l|c|c|c|c|c|c|c|}
\hline \multirow{2}{*}{ Metrics } & \multicolumn{9}{c|}{ Year } \\
\cline { 2 - 9 } & 2009 & 2011 & 2013 & 2015 & 2017 & 2018 & 2019 \\
\hline Total number of countries in the ranking & 114 & 110 & \multicolumn{2}{|c|}{142} & 149 & \multicolumn{2}{c|}{167} \\
\hline Cumulative rating of the country & $69 / 86^{*}$ & 74 & 64 & 70 & 112 & $111 / 99^{*}$ & 96 \\
\hline Governance & 98 & 99 & 121 & 120 & 130 & 129 & 81 \\
\hline Security & 58 & 56 & 55 & 54 & 125 & 128 & 145 \\
\hline Personal freedom & 71 & 98 & 107 & 91 & 95 & 90 & 85 \\
\hline Social capital & 73 & 37 & 36 & 41 & 115 & 119 & 148 \\
\hline Quality of economic development & $\times$ & $\times$ & $\times$ & $\times$ & $\times$ & 97 & 99 \\
\hline Environment of business development & $\times$ & $\times$ & $\times$ & $\times$ & $\times$ & 106 & 71 \\
\hline Education & $\times$ & $\times$ & $\times$ & $\times$ & $\times$ & 43 & 37 \\
\hline Health & $\times$ & $\times$ & $\times$ & $\times$ & $\times$ & 137 & 114 \\
\hline Natural environment & $\times$ & $\times$ & $\times$ & $\times$ & $\times$ & 105 & 127 \\
\hline Investment environment & $\times$ & $\times$ & $\times$ & $\times$ & $\times$ & $\times$ & 113 \\
\hline Development of market infrastructure & $\times$ & $\times$ & $\times$ & $\times$ & $\times$ & $\times$ & 87 \\
\hline Living condition & $\times$ & $\times$ & $\times$ & $\times$ & $\times$ & $\times$ & 69 \\
\hline
\end{tabular}

Source: (The Legatum Prosperity Index, 2019)

Notes: according to LPI data listed according to the 2019 methodology 
Vol. 1, No. 4, 2020

Table 4

Quantitative assessment of Ukraine' SKNE in the process of WGI indicators' calculating

\begin{tabular}{|c|c|c|c|c|c|c|c|c|c|c|}
\hline \multirow{2}{*}{\multicolumn{2}{|c|}{ Metrics }} & \multicolumn{9}{|c|}{ Year } \\
\hline & & 2011 & 2012 & 2013 & 2014 & 2015 & 2016 & 2017 & 2018 & 2020 \\
\hline \multirow{2}{*}{ Index } & rank & 105 & 111 & 102 & 103 & 89 & 106 & 90 & 81 & 101 \\
\hline & value & 26 & 21 & 24 & 23 & 29 & 26 & \multicolumn{2}{|c|}{29} & 24 \\
\hline Donations & \multirow{3}{*}{$\%$} & 11 & 7 & 8 & 9 & 38 & 26 & \multicolumn{2}{|c|}{29} & 18 \\
\hline Volunteer hours & & 30 & 20 & 29 & 26 & 13 & 16 & \multicolumn{2}{|c|}{15} & 19 \\
\hline Help strangers & & 37 & \multicolumn{2}{|c|}{36} & 35 & \multicolumn{2}{|c|}{36} & \multicolumn{2}{|c|}{42} & 35 \\
\hline
\end{tabular}

Source: (World giving Index $10^{\text {th }}$ edition, 2019)

the environment, is based on the use of 104 indicators: Gallup World Survey, World Development Indicators, International Telecommunication Union, Fragile States Index, World Governance Indicators, Freedom House, World Health Organization, World Values Survey, Amnesty International, Center for System Peace.

In the end, Bertelsmann Stiftung's Transformation Index (BTI) comprehensively assesses political and economic transformations and the level of political leadership in Ukraine using criteria grouped by indicator groups (Table 5).
Additional information on the state of formation of individual elements of SCNE of Ukraine can be obtained in case of settlements on the method of calculating Freedom Index; Economic Freedom of the World; Compliance Summary Index ESF; S\&P (Standard \& Poor's Ratings Services, 2019); Moody's (Moody's Investors Service, 2019); World Bank Governance Indicator - Voice and Accountability (VA), Government Effectiveness (GE), Regulatory Quality (RQ), Rule of Law (RL), Control of Corruption (CC); World Factbook (World Factbook, 2019); Freedom Barometer for Europe.

Table 5

Quantitative evaluation of Ukraine' linking social capital in the process of BTI' calculating

\begin{tabular}{|c|c|c|c|c|c|c|c|c|}
\hline \multirow{2}{*}{\multicolumn{2}{|c|}{ Indicators on 10-point scale }} & \multicolumn{7}{|c|}{ Year } \\
\hline & & 2010 & 2012 & 2014 & 2016 & 2018 & \multicolumn{2}{|c|}{2019} \\
\hline \multicolumn{9}{|c|}{ Status index } \\
\hline \multicolumn{2}{|c|}{ Rating of Ukraine } & 37 & $\ldots$ & $\ldots$ & $\ldots$ & 36 of 129 & \multicolumn{2}{|c|}{41 of 162} \\
\hline \multicolumn{2}{|c|}{ The numerical value of the index } & 6.6 & ... & $\ldots$ & $\ldots$ & 6.54 & \multirow{2}{*}{\multicolumn{2}{|c|}{$\begin{array}{c}72.8 \text { to } 70.4 \\
\text { for region in average } \\
\text { SDG trends }\end{array}$}} \\
\hline \multicolumn{7}{|c|}{ Political transformation (democratic status) } & & \\
\hline \multicolumn{2}{|c|}{ Rating of Ukraine } & \multicolumn{4}{|c|}{$\ldots$} & 36 of 129 & \multirow{2}{*}{ SDG 1} & \multirow{2}{*}{$\downarrow$} \\
\hline \multicolumn{2}{|c|}{ The numerical value of the index } & 6.9 & \multicolumn{2}{|c|}{6.1} & 6.8 & 6.9 & & \\
\hline \multirow{5}{*}{ 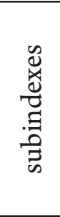 } & statehood & \multicolumn{3}{|c|}{8.8} & 7.3 & \multirow{2}{*}{7.5} & SDG 2 & $\rightarrow$ \\
\hline & participation in political life & 7.8 & \multicolumn{2}{|c|}{6.0} & 7.8 & & SDG 3 & $\pi$ \\
\hline & rule of low & 6.3 & \multicolumn{2}{|c|}{5.0} & \multicolumn{2}{|r|}{6.3} & SDG 4 & $\ldots$ \\
\hline & stability of democratic institution & 6.5 & \multicolumn{2}{|c|}{5.5} & 7.0 & 7.5 & SDG 5 & $\rightarrow$ \\
\hline & political and social integration & 5.8 & \multicolumn{2}{|c|}{5.3} & 5.5 & 5.8 & SDG 6 & $\rightarrow$ \\
\hline \multicolumn{7}{|c|}{ Economic transformation (market status of the economy) } & \multirow{2}{*}{ SDG 7} & \multirow[b]{2}{*}{$\cdots$} \\
\hline \multicolumn{2}{|c|}{ Rating of Ukraine } & \multicolumn{4}{|c|}{$\ldots$} & 43 of 129 & & \\
\hline \multicolumn{2}{|c|}{ The numerical value of the index } & 6.2 & 5.8 & 5.7 & 5.4 & 6.18 & SDG 8 & $\uparrow$ \\
\hline \multirow{4}{*}{ 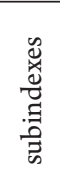 } & stability & & 5.5 & & 5.0 & 5.5 & SDG 9 & $\pi$ \\
\hline & welfare regime & & & 6.0 & 6,5 & 65 & SDG 10 & $\ldots$ \\
\hline & private property & & & 5.5 & .0 & 0.5 & SDG 11 & $\downarrow$ \\
\hline & socioeconomic level of development & & & 6.0 & & 5,0 & CDC 19 & \\
\hline & Ind & & & & & & SDG 12 & $\cdots$ \\
\hline Ratin & g of Ukraine & & & & & 49 of 129 & SDG 13 & $\uparrow$ \\
\hline The $\mathrm{r}$ & umerical value of the index & 5.4 & 4.6 & 4.3 & & 5.41 & SDG 14 & $\ldots$ \\
\hline & subordinates to management procedures & 6.0 & 5.7 & 4.7 & 5.7 & SDG & SDG 15 & $\pi$ \\
\hline 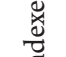 & resource efficiency & 5.3 & & & 4.7 & 5.3 & SDG 16 & $\downarrow$ \\
\hline$\stackrel{\Xi}{\overparen{7}}$ & development of cooperation & 5.8 & & & 5.4 & 5.8 & SDG 17 & 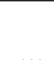 \\
\hline & international cooperation & 7.0 & 6.7 & 6.0 & 6.7 & 7.0 & & $\cdots$ \\
\hline
\end{tabular}

Source: (The SDG Index, 2019) 


\section{Discussions}

Cross-cultural research, regardless of the fundamental principles on which they are carried out strategic or rational concepts (Hardin's encapsulated interest; Stolle's past experience, confidence in security ("assurance of security") Yamagishi, Rosenberg's "faith in people"); concepts of group identity (TejfelTurner categorization theory, decategorization/ personalization/intergroup differentiation/universal identity of Gertner-Dovidio-Howlett); concepts of moral norms (Uslaner) - do not give an unambiguous answer to the question, which in quantitative terms is the level of generalized trust in the country, the contribution of this indicator to the formation of the level of well-being of its citizens. This is due to a wide range of reasons that explain the differences in approaches to understanding the term "majority" in different cultural traditions (ranges from in-group to out-group), differences in public trust indicators (absolute "trust in most people" as opposed to "trust in people, which you meet for the first time"), between the worldview "trust settings", the norm that is assimilated in the process of socialization and remains unchanged throughout life, real behavior, which is determined by a situational assessment of the level of reliability of others, determination of the degree of risk, the likelihood of positive/negative consequences.

\section{Conclusions}

For SCNE of Ukraine is inherent in the simultaneous deep commitment of the domestic community to the values of survival (at the level of Russia, Moldova, Romania, Albania, Bulgaria) in combination with a high level of confession of secular rational values (at the level of Lithuania, South Korea, the Czech Republic, Germany, Denmark). Stronger and more reliable, such that the "moral trust" to the members of outgroups, which is inherent in more developed countries (Sweden, Norway), in which trust in strangers and the majority at the same time is relatively high, is contrasted with the mobile, more plastic and specific "rational trust" in the members of in groups (Tinidad and Tobago, Burkina Faso, Ghana, South Africa, Mali, France). This indicates the lack of cultural universality of this phenomenon. An outgroup that intensifies in a situation of tension or conflict may be interpreted as an indicator of tolerance. Ukraine is characterized by a specific development of trust categories both at the level of ingroups and outgroups, and the level of "moral" and "rational" trust in dynamics. Based on the above data, Ukraine has a low level of direct interpersonal social trust (the level of distrust/caution in relations practically exceeds it three times) combined with a low level of trust in political institutions. The necessary information for the assessment of the environment and the general level of development of the SKNE of Ukraine is contained in the already mentioned international indices, which in their aggregate comprehensively characterize the subject of our research.

\section{Acknowledgement}

The paper was supported by Erasmus+ Project № 609944-EPP-1-2019-1-LT-EPPKA2-CBHE-JP

"Enhancing Capacity of Universities to Initiate and to Participate in Clusters Development on Innovation and Sustainability Principles".

\section{References:}

Arsawan, I. W. E., Koval, V., Rajiani, I., Rustiarini, N. W., Supartha, W. G. \& Suryantini, N. P. S. (2020). Leveraging knowledge sharing and innovation culture into SMEs sustainable competitive advantage. International Journal of Productivity and Performance Management. doi: 10.1108/IJPPM-04-2020-0192

Baklanova, O., Petrova, M., \& Koval, V. (2020). Institutional Transmission in Economic Development. Ikonomicheski Izsledvania, 29(1), 68-91.

Bukanov H., Kolesnyk A., Tashkinova O., Kotlubai V., \& Koval V. (2019). Social marketing in public administration of social service institutions. Revista Genero \& Direito, 8(6), 457-468.

Carillo Alvarez, E., \& Riera-Romani, J. (2017). Measuring social capital: futher insights. Gaceta Sanitaria, 31, 57-61. Corruption Perception Index (2019). Transparency International. Available at: https://www.transparency.org/en/ cpi/2019/results/ukr (accessed 09 November 2020).

Enabling Environment Index. A Civicus initiative (2013). The EEI. Available at: https://www.civicus.org Global Competitiveness Index 4.0 (2018). World Economic Forum. Available at: https://reports.weforum.org Global Peace Index. Measuring peace in a complex world (2019). Institute for Economics Peace. Available at: http://visionofhumanity.org

Gross National Income per capita. Atlas method and Purchasing power parity (international \$) (2019). The World Bank. Available at: https://databank.worldbank.org/data/

Helliwell, J. F., Layard R., \& Sachs J. D. (2019) World Happiness Report. Available at: https://s3.amazonaws.com Human Development Reports (2019). United Nations Development Programme. Human Development Index Ranking. Available at: http://hdr.undp.org/en/content/2019-human-development-index-ranking (accessed 02 November 2020). 
Inglehart, R., Haerpfer, C., Moreno, A., Welzel, C., Kizilova, K., Diez-Medrano, J., Lagos, M., Norris, P., Ponarin, E., \& Puranen, B. et al. (eds.) (2018). World Values Survey: Round Six - Country-Pooled Datafile. Madrid, Spain \& Vienna, Austria: JD Systems Institute \& WVSA Secretariat. doi: 10.14281/18241.8

Kanso, A. (2019). Organizational and economic mechanism of regulation of social capital of the national economy. Black Sea Economic Studies, 43, 195-200.

Koval, V., Prymush, Y., \& Popova, V. (2017). The influence of the enterprise life cycle on the efficiency of investment. Baltic Journal of Economic Studies, 3(5), 183-187. doi: 10.30525/2256-0742/2017-3-5-183-187

Moody's Investors Service (2020). Ratings Symbols and Definitions. Available at: https://www.moodys.com/sites/ products

Nahapiet. J., \& Ghoshal, S. (1998). Social capital, intellectual capital, and the organizational advantage. Academy of Management Review, vol. 23, no. 2: 242-266. doi: 10.2307/259373 (accessed 25 November 2020).

Petrova, M., Koval, V., Tepavicharova, M., Zerkal, A., Radchenko, A., \& Bondarchuk, N. (2020). The interaction between the human resources motivation and the commitment to the organization. Journal of Security and Sustainability Issues, 9(3), 897-907. doi: 10.9770/jssi.2020.9.3(15)

Pichler, F., \& Wallace, C. (2007). Patterns of Formal and Informal Social Capital in Europe. European Sociological Review, vol. 23, issue 4: 423-435. doi: 10.1093/esr/jcm013 (accessed 01 December 2020).

Rui, J. R., Covert, J. M., Stefanone, M. A., \& Mukherjee, T. (2014). A Communication Multiplexity Approach to Social Capital: On- and Offline Communication and Self-Esteem. Social Science Computer Review, 33(4).

Standard \& Poor's Ratings Services (2020). McGraw Hill Financial. Available at: http://www.maalot.co.il/ publications

Sustainable Development Goals. Sustainable Development Knowledge Platform. unescap.org. Available at: https://https://www.unescap.org/2030-agenda/sustainable-development-knowledge-platforms 0 (accessed 28 November 2020).

The Global Sustainable Competitiveness Index (2020). Solubility. Available at: http://solability.com/solubility/ sustainability-publications/the-global-sustainable-competitiveness-index-2 (accessed 24 November 2020).

The Legatum Prosperity Index (2019). Legatum Institute. Available at: https://prosperitysite.s3-accelerate. amazonaws.com/1515/8634/9128/The_Legatum_Prosperity_Index_2019_Rankings_Table.pdf (accessed 06 November 2020).

The SDG Index (2019). Sustainable Development Solution Network Bertelsmann Stiftung. Available at: https://s3.amazonaws.com

Villalonga-Olives, E., Adams, I., \& Kawachi, I. (2016). The development of a bridging social capital questionnaire for use in population health research. Population Health, vol. 2. doi: 10.1016/j.ssmph.2016.08.008

World Factbook (2018). Central Intelligence Agency. Available at: https://www.cia.gov/library/publications/ download/download-2018/index.html

World giving Index $10^{\text {th }}$ edition (2019). Charities Aid Foundation. Available at: https://www.cafonline.org/ about-us/publications 